\title{
Sustainable Development: A Literature Review
}

\author{
Dr. Saroj Kumar Singh $^{1 *}$
}

\section{ABSTRACT}

Sustainable development - as a well-defined concept - has emerged from a series of Conferences and Summits, where influential people have tried to come to an agreement on how to tackle the "burning issues" of the 21st Century: poverty, increasing inequality, environmental and human health degradation. The present paper presents the most important "stages," where the "actors" have created and defined the concept of sustainable development and its principles.

Keywords: Sustainable Development, Environment, Economic Growth.

Sustainable development has become the "buzzword" of both the academic and the business world. "Sustainability" has been present for the last decades in academic papers, syllabuses of Faculties, boardrooms of local authorities and corporations and offices of public relations officers. Unfortunately, sustainability has become a "fashionable" concept in theory, but it is considered extremely expensive to be put in practice by major corporations, firms and local or national governments.

What people tend to neglect and forget is the evolution of the concept of sustainability. Although the history and evolution of a concept might seem unimportant, it could help us predict the future trends and flaws that will appear. And it will help us ensure that the 21st century will be "the Sustainability Century” (Elkington, 1997, p.18).

\section{THE “ALARM BELLS”}

More than 200 years ago, the first questions arose regarding the impact of the evolution of our civilization could have on the environment and resources of our planet. In 1798, Thomas Robert Malthus (1766-1834), demographer, political economist and country pastor in England wrote An Essay on the Principle of Population. He predicted that the world's population would eventually starve or, at the least, live at a minimal level of subsistence because food production could not keep pace with the growth of population.

\footnotetext{
${ }^{1}$ Assistant Professor (Senior Scale), S. N. S. R. K. S. College, Saharsa PIN 852201 (A constituent unit of B.N.M. U. Madhepura, Bihar, India

*Responding Author

(C) 2016 I S Singh; licensee IJIP. This is an Open Access Research distributed under the terms of the Creative Commons Attribution License (http://creativecommons.org/licenses/by/2.0), which permits unrestricted use, distribution, and reproduction in any Medium, provided the original work is properly cited.
} 


\section{Sustainable Development: A Literature Review}

He believed that the population was held in check by “misery, vice and moral restraint”. Malthus wrote that "population, when unchecked, increased in a geometrical ratio and subsistence for man in an arithmetical ratio” (Rogers, 2008, p. 20). Technological advances since that time have proved him wrong. Through better farming techniques, the invention of new farming equipment, and continuing advances in agricultural science, "production has increased much more rapidly than population, so much so that in real terms, the price of food is much lower today than it was two hundred years ago, or for that matter, even fifty years ago” (Baumol, 2007, p. 17).

The debate about Malthusian limits has continued in time, with many critics asking how it became possible to have a six-fold increase in global population - from one to six billion - since 1798 and still be able to more or less feed the population. The next wave of Malthusianism is represented by the ideas and prospects presented by the Club of Rome. The results of computer simulations made by MIT technicians were published in the well-known book The Limits to Growth (Meadows, 1972) which focused attention on depletion of nonrenewable resources and resulting increases in commodity prices. "Additionally, this model assumed that population and industrial capital would continue to grow exponentially, leading to a similar growth in pollution and in demand for food and non-renewable resources” (Cole, 2007, p. 241).

The supply of both food and non-renewable resources was assumed to be fixed. Not surprisingly given the assumptions, the model predicted collapse due to non-renewable resource depletion. At the same time, one of their conclusions remarks, "there is no extraordinary effort to abate pollution or conserve resources." However, as time passed, "most if not all of the Club of Rome's predictions for the next 30 years, from 1973 to 2003 were not borne out” (Rogers et. al., 2008, p. 20).

Another Malthusian worth mentioning is Lester Brown. He has published numerous books (latest: Plan B 2.0: Rescuing a Planet under Stress and a Civilization in Trouble in 2006 and Plan B 3.0: Mobilizing to Save Civilization in 2008) and articles dealing with the troubles that our civilization will face after we will exhaust our fossil fuel reserves. In 1974, Lester Brown has set up the World Watch Institute and later on the Earth Policy Institute. Both of them are presenting facts regarding the global use of natural resources and presenting viable alternatives for our consumption trends (Brown, 2006, p.17).

The main purpose of the above mentioned Malthusians was to provide a useful reminder to the society and to the local, national and international authorities that if we continue our consumption trends we could find ourselves in trouble.

\section{THE EMERGENCE OF THE CONCEPT}

The 1972 Conference on the Human Environment in Stockholm, Sweden, attended by 113 states and representatives from 19 international organizations, was the first truly international conference devoted exclusively to environmental issues. There, a group of 27 experts articulated 


\section{Sustainable Development: A Literature Review}

the links between environment and development stating that: "although in individual instances there were conflicts between environmental and economic priorities, they were intrinsically two sides of the same coin” (Vogler, 2007, p. 432). Another result of the Stockholm Conference was the creation of the United Nations Environmental Program (UNEP), which has the mission "to provide leadership and encourage partnership in caring for the environment by inspiring, informing, and enabling nations and peoples to improve their quality of life without compromising that of future generations.”

This conference played a catalytic role in promoting the subsequent adoption of international agreements concerned with ocean dumping, pollution from ships, and the endangered species trade. It also adopted the "Stockholm Declaration on the Human Environment," which included forward-looking principles, such as Principle 13167, that declared the need for integration and coordination in development planning to allow for environmental protection. However, "the Stockholm conference was limited in its effectiveness because environmental protection and the need for development, especially in developing countries, were seen as competing needs and thus were dealt with in a separate, uncoordinated fashion". Some critics concluded that "the conference was more concerned with identifying trade-offs between environment and development than with promoting harmonious linkages between the two" (Prizzia, 2007, p. 21). Even UN documents acknowledged after the Stockholm conference that little was accomplished to concretely integrate environmental concerns into development policies and plans. A more integrated perspective that incorporated both economic development and environmental sensitivities was clearly needed.

In 1983, the UN General Assembly created the World Commission on Environment and Development which was later known as the Brundtland Commission, named after its Chair, Gro Harlem Brundtland, then Prime Minister of Norway and later head of the World Health Organization. In 1987, the Commission published the Brundtland Report, entitled Our Common Future. It built upon what had been achieved at Stockholm and provided the most politically significant of all definitions of sustainable development: "sustainable development is development that meets the needs of the present without compromising the ability of future generations to meet their own needs." The definition contains two major concepts: firstly, the concept of 'needs', in particular, the essential needs of the world's poor, to whom overriding priority should be given; and secondly the idea of limitations imposed by the state of technology and social organization on the environment's ability to meet present and future needs.

In that period the concept of sustainable development acquired political momentum "through rising public concern in the developed countries over the new and alarming phenomenon of global environmental change, and in some ways it replaced fears of nuclear war that had prevailed in the early 1980’s” (Vogler, 2007, p. 435). 


\section{Sustainable Development: A Literature Review}

Some critics argue that "the Brundtland Commission Report's discussion of sustainability is both optimistic and vague. The Commission probably felt that, in order to be accepted, the discussion had to be optimistic, but given the facts, it was necessary to be vague and contradictory in order not to appear to be pessimistic" (Bartlett, 2006, p. 22). Others are even more critical: "Mrs. Brundtland provided a slogan behind which first world politicians with green electorates to appease, and third world politicians with economic deprivation to tackle, could unite. The formula was of course vague, but the details could be left for later” (Benton, 1994, p. 129). But the fact still remains that the concept of sustainable development was born.

\section{TAKING THE CONCEPT TO THE NEXT LEVEL}

The next step was the UN Conference on the Environment and Development (UNCED), which was held in Rio de Janeiro, Brazil, during the summer of 1992, an unprecedented historical event with the largest gathering of 114 heads of state, including 10,000 representatives from 178 countries and 1400 nongovernmental organizations represented by additional thousands.

The conference itself proved to be an international event on an unprecedented scale as heads of government tried to make their mark on what was dubbed the Rio Earth Summit. The association in the title, "connecting Environment and Development, was indicative of North-South bargaining at the UN, in which demands for international action on the environment were set against claims for additional development aid and technology transfer” (Vogler, 2007, p. 436). The key outputs of the Conference were: the Rio Declaration, Agenda 21173, and the Commission on Sustainable Development. All are quite explicitly concerned with sustainable development and it is thus, at the conclusion of the Earth Summit that the concept truly arrives on the international scene.

The commitment of leaders from around the world to sustainable development was clearly articulated in Agenda 21, the key document of the summit - a 500 page collection of agreed healthy practices and advices for achieving sustainable development in almost any area on the surface of the earth. Agenda 21 activities are organized under environmental and development themes: quality of life, efficient use of natural resources, protection of the global commons, management of human settlements, and sustainable economic growth. It recognizes that the persistence of severe poverty in several parts of the world alongside a standard of living based on wasteful consumption of resources in other parts is not a sustainable model, and that environmental management must be practiced in developing and industrial countries alike.

During the 1992 conference, it was agreed that to implement Agenda 21, countries should prepare a national sustainable development strategy.

While sustainable development was the unifying principle for the entire Rio conference, there was disagreement about its meaning and implications. The UNCED process attempted to provide guidance in implementing sustainable development by laying out a set of principles and a plan of action based on the concept. Indeed, Rio was less about debating the definition of sustainable 


\section{Sustainable Development: A Literature Review}

development than it was about developing approaches to ensure its implementation. Some critics argue that "implementing the principles of equity and living within ecological limits can only be accomplished if social, political, and economic systems have the flexibility to be redirected toward sustainability as well as integrated with each other and the environment” (Prizzia, 2007, p. 21).

In the 1997 Kyoto conference on climate change, developed countries agreed on specific targets for cutting their emissions of greenhouse gases, resulting in a general framework, which became known as the Kyoto Protocol, with specifics to be detailed over the next few years. The U.S. proposed to stabilize emissions only and not cut them at all, while the European Union called for a $15 \%$ cut. In the end, there was a trade off, and industrialized countries were committed to an overall reduction of emissions of greenhouse gases to 5.2\% below 1990 levels for the period 2008-2012. However, the complexity of the negotiations created considerable confusion over compliance even after the Kyoto Protocol itself was adopted because it only outlined the basic features for compliance but did not explain the all-important rules of how they would operate. Although 84 countries signed the Protocol, indicating their intent to ratify it, many others were reluctant to take even this step.

Unfortunately, the USA has refused to ratify the Kyoto Protocol. The EU has ratified the Kyoto protocol but this has not been enough. The Union has failed to reduce CO2 emissions. The overall picture of the situation in 2030 is pessimistic. In relation to 1990 figures, the US's contribution to $\mathrm{CO} 2$ emissions will increase by $50 \%$, compared to an $18 \%$ EU increase (Camhis, 2006 p. 74). The Kyoto Protocol remains one of the most debated international agreements between the "greens" and the "neo-liberals."

In September 2000 at the Millennium Summit held in New York, world leaders agreed on the Millennium Development Goals, most of which have the year 2015 as a timeframe and use 1990 as a benchmark.

These goals are both modest and ambitious. The Millennium Development Goals demonstrate that "the livelihoods and well-being of the world's poor are now conceptualized in terms of access to opportunity and absence of insecurity and vulnerability" (Adger et. al., 2007, p. 194). They represent a more practical expression of the principle of equilibrium between the economic, social and environmental pillars of sustainable development. They include 1) halving the proportion of people living on less than a dollar a day and those suffering from hunger, 2) achieving universal primary education and promoting gender equality, 3) reducing child mortality and improving maternal health, 4) reversing the spread of HIV/AIDS, 5) integrating the principles of sustainable development into country policies, 6) reducing by half the proportion of people without access to safe drinking water. Unfortunately, the world still has to tackle "this dangerous blend of indifference and concealment and ultimately rebuild the trust between people, business and government, desperately needed if we are going to stand any chance in 
achieving the Millennium Development Goals to combat poverty, disease and deprivation by 2015” (Gorbachev, 2006, p.157)

The World Summit on Sustainable Development (WSSD) in Johannesburg in 2002 was a landmark in the business of forging partnerships between the United Nations, governments, business and NGOs to gather resources for addressing global environment, health and poverty challenges. The Johannesburg Summit reconfirmed the Millennium goals and complemented them by setting a number of additional ones such as halving the proportion of people lacking access to basic sanitation; minimizing harmful effects from chemicals; and halting the loss of biodiversity. Some authors consider the summit a "progress in moving the concept [of sustainable development] toward a more productive exploration of the relationship between economic development and environmental quality" (Asefa, 2005, p. 1). The WSSD “fills some gaps in the Agenda 21 and the Millennium Development Goals and addresses some newly emerging issues, including to halve the proportion of people without access to basic sanitation by 2015; to use and produce chemicals by 2020 in ways that do not lead to significant adverse effects on human health and the environment; to maintain or restore depleted fish stocks to levels that can produce the maximum sustainable yield on an urgent basis and where possible by 2015; and to achieve by 2010 a significant reduction in the current rate of loss of biological diversity" (Nelson, 2007, p. 166).

The Johannesburg Conference confirmed a trend, which appeared since the 1992 Conference, of the increasing importance of the socioeconomic pillars of sustainable development. The environmental agenda at the two previous UN conferences had been sustained by peaks in the public 'attention cycle' of major developed countries. WSSD incorporated the concept of sustainable development throughout its deliberations and was initially dubbed "the implementation summit." Inevitably, “demands for additional financial resources and technology transfer continued but much of the debate had already been pre-empted by the establishment of the Millennium Development Goals in 2000” (Vogler, 2007, p. 439).

\section{CONCLUSIONS}

If we follow all the conferences from 1972 to 2002 we can observe that there was the shift in the political debate from a primary emphasis on environmental issues at the 1972 Stockholm Conference, through a shared focus on environmental, social and economic development at the Rio de Janeiro Earth Summit in 1992, to arguably a primary emphasis on poverty alleviation at the Millennium Summit in 2000 and at the Johannesburg World Summit in 2002. This does not necessarily mean environmental protection has been effectively sidelined, of interest mainly in its capacity to alleviate poverty. Rather, it would appear that what began as a call to protect the environment in the service of human development has become a more specific call to prioritize improvements in the well-being of the very worst-off now and in the future. The biggest challenge of sustainable development remains the global consciousness from households to 
boardrooms regarding the importance of tackling the challenges of the Industrial Revolution: a limitless human and environmental exploitation.

\section{REFERENCES}

Adger Neil, Winkles Alexandra (2007) - Vulnerability, poverty and sustaining wellbeing, published in Handbook of Sustainable Development, Edward Elgar Publishing Limited, Cheltenham

Asefa, Sisay (2005) - The Concept of Sustainable Development: An Introduction, published in The Economics of Sustainable Development, W.E. Upjohn Institute for Employment Research, Michigan

Bartlett, Albert (2006) - Reflections on Sustainability, Population Growth, and the Environment, published in The Future of Sustainability, Springer, Dordrecht

Baumol William, Litan R., Schramm C. (2007) - Good Capitalism, Bad Capitalism, and the Economics of Growth and Prosperity, Yale University Press, New Haven \& London

Benton, Theodore (1994) - The Greening of Machiavelli, The Evolution of International Environmental Politics, London: Royal Institute of International Affairs/Earthscan

Brown, Lester (2006) - Plan B 2.0: Rescuing a Planet under Stress and a Civilization in Trouble, W.W. Norton \& Company, New York

Camhis, Marios (2006) - Sustainable Development and Urbanization, published in The Future of Sustainability, Springer, Dordrecht

Cole, Matthew (2007) - Economic growth and the environment, published in Handbook of Sustainable Development, Edward Elgar Publishing Limited, Cheltenham

Gorbachev, Mikhail (2006) - A New Glasnost for Global Sustainability, published in The Future of Sustainability, Springer, Dordrecht

Lam, David (2005) - How the World Survived the Population Bomb: An Economic Perspective, published in The Economics of Sustainable Development, W.E. Upjohn Institute for Employment Research, Michigan

Nelson, Lisa (2007) - The role of the United Nations: from Stockholm to Johannesburg, published in Handbook of Globalization and the Environment, CRC Press, Boca Raton

How to cite this article: S Singh (2016), Sustainable Development: A Literature Review, International Journal of Indian Psychology, Volume 3, Issue 3, No. 6, DIP: 18.01.104/20160303 